\title{
AUTO SACRAMENTAL DEL JUEGO DEL HOMBRE, DE LUIS MEJÍA DE LA CERDA. EDICIÓN CRÍTICA ${ }^{1}$
}

\author{
DAVINIA RodRÍGUEZ ORTEGA \\ Universidad Pública de Navarra \\ davinia.rodriguez@unavarra.es
}

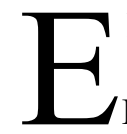

1 Auto Sacramental del Juego del Hombre, escrito por Luis Mejía de la Cerda en 1625, se conserva en la Biblioteca Nacional de España, ms. 14873. Es un autógrafo con correcciones (partes añadidas y versos tachados) y con indicaciones asimismo de su representación (los nombres de los actores Ana Cabello, Juan Bautista y Alonso Fernández figuran escritos en la lista de personajes); el manuscrito proviene de la Biblioteca de Osuna e Infantado y presenta manchas de humedad, además de estar deteriorado en los bordes, lo que hace ilegible en ocasiones la primera línea de cada folio.

El auto se configura a partir de la recreación de dos parábolas neotestamentarias: la semilla y la cizaña y el sembrador. Es posible decir, siguiendo las palabras de Menéndez Pelayo (1943: Lv), que dichos textos con intención didáctica y devocional se convirtieron en un sustrato privilegiado para la composición de obras sacramentales, puesto que en la mayoría de las ocasiones ya presentaban la enseñanza propuesta vertida al modo alegórico. Siguiendo esta favorecida relación, los dos grandes ingenios de la literatura aurisecular, Lope de Vega y Calderón de la Barca, escribieron sendos autos sacramentales, de título La siega y La semilla y la cizaña respectivamente, que pueden ser comparados por inspirarse en los mismos pasajes neotestamentarios. A pesar de compartir la base bíblica, cada texto presenta las características distintivas del autor, partiendo del modo en que los dramaturgos concebían el género, siendo más lírico el texto lopiano y mejor estructurada y contundente la pieza de Calderón ${ }^{2}$. De este modo, puede inscribirse

\footnotetext{
1 Este trabajo se ha llevado a cabo gracias a una ayuda posdoctoral de la Universidad Pública de Navarra.

2 La relación entre los tres autos puede encontrarse en Rodríguez Ortega (2012: 20-26) y entre los autos de Lope y Calderón, en Rodríguez Ortega (2015a).
}

Edad de Oro, XXXIV (2015), pp. 219-269, ISSN: 0212-0429 - DOI http://dx.doi.org/10.15366/edadoro2015.34.014 
en la tradición mencionada el manuscrito que nos ocupa, al tomar como inspiración las narraciones de Jesús en el desierto; no obstante, el auto de Mejía de la Cerda presenta una peculiaridad de la que el resto de muestras carecen: la inserción del tópico de los naipes en una composición de teatro religioso. Mientras la parte bíblica, con abundantes referencias y alusiones, se ubica como centro en la primera mitad del auto, durante el clímax y el desenlace el argumento se dibuja en torno a una partida de naipes entre el Hombre, el Mundo, Cristo y la Muerte, cuyo trágico final es por todos conocido.

Si la calidad literaria del auto no es destacable, sí es un ejemplo único de confluencia de motivos, en principio antagónicos, como pueden ser la fe y el juego, en un texto sacramental ${ }^{3}$. Como consecuencia, a continuación se ofrece una edición crítica y anotada a partir del manuscrito autógrafo conservado, tarea facilitada también por la transcripción llevada a cabo por Louis Imbert en 1915. En lo relativo a cuestiones editoriales, las grafías sin relevancia lingüística se han modernizado y la puntuación ha sido revisada; se han encontrado algunos errores de copia en el texto de Imbert que se han modificado de acuerdo con el manuscrito durante el proceso de cotejo, sin que se indique en nota. Por el contrario, sí se mencionan los cambios incluidos respecto a la versión original, acompañados de las indicaciones pertinentes.

3 Para ampliar esta información se puede consultar Rodríguez Ortega (2015b). 


\section{A et $\Omega$}

Auto Sacramental del Juego del Hombre Fundado Sobre la Parábola del Sembrador y de la Cizaña, Mathui C [13]: Simile Factum est Regnum Coelorum Homini qui Seminavit Bon[um] Semen in Agro Suo. Feliciter incipit sub censura et corectione Sanctae Matris Ecclesiae Catholiçe R[o]mane.

-Figuras de este auto-

Cristo, labrador del cielo y buen sembrador. Nuestra Señor[a $]^{1}$

Luzbel, sembrador de cizaña. Alonso Fernández

Celo, guarda de los trigos, de villano.

La Verdad, de villana. Ana Cabello

El Hombre, galán. Juan Bautista

El Mundo, galán.

Los Gustos, que son los músicos.

La Muerte.

Sale Cristo, labrador del cielo, vestido de labrador y prevenido para sembrar. Con él, sale el Celo vestido de galán, una zagaya ${ }^{2}$ en la mano y ceñida una honda $a^{3}$ colgada del ceñidor.

CELO

CRISTO

CELO

CRISTO
Tuyo el mundo ${ }^{4}$.

No lo dudes.

Tierra infructífera tienes.

Celo, si a guardarla acudes, sembrarela de mis bienes, regaranla mis virtudes;

fruto coge quien bien labra.

\footnotetext{
1 Probablemente el autor olvidó incluir el personaje de la Virgen en la lista de dramatis personae, de ahí que se encuentre junto al de Cristo, rompiendo con la disposición de página prevista.

2 zagaya: (azagaya) «Lanza pequeña que usan los montañeses. El padre Guadix dice que aaça en arábigo vale lanza y de allí se dijo azagaya, lanza pequeña» (Cov.).

3 honda: «Es la honda arma peculiar de los pastores; y así el pastorcico David, habiendo salir al desafío con Goliat, desecha las armas de Saúl, y va a pelear con sola su honda y cinco guijarros pelados que escogió de un arroyo, y con el primero le derribó» (Cov.). Gracias a este accesorio, se identifica al Celo con el israelita David en cuanto a su función dramática como guardián de los sembrados; de este modo, el propio nombre del personaje y su caracterización ayudan a configurarlo como actante en la pieza.

4 Este verso pronunciado por el Celo ayuda al espectador a identificar al otro personaje en escena como Cristo; la referencia bíblica puede tomarse de Salmos, 89, 12: «Tuyo es el cielo, tuya también la tierra, tú formaste el mundo y todo lo que contiene».
} 
Celo

Antes que sus fuentes abra

el cielo y pase el noviembre,

tu deidad el trigo siembre

de su divina palabra;

Celo soy, y el de tu casa

me ha comido de manera

que esta tierra, pingüe y crasa,

logrará su sementera

si la niebla no lo abrasa.

Seré un lince vigilante, cuyo silbo al orbe espante, y cuando el eco responda será de David la honda contra Goliat el gigante ${ }^{5}$.

Guarda seré de este trigo, símbolo de tus eletos ${ }^{6}$, que si tus caminos sigo no ha de llegar a sus setos la sombra del enemigo. Esta parda es gentil era.

CRISTO Pues por semilla primera de mi celeste caudal, sea la ley natural ${ }^{7}$ principio de sementera.

Un sacramento profundo

los sacros cielos coligen

de esta ley que siembro y fundo;

pues su verdad tuvo origen

del primer (fíat) ${ }^{8}$ del mundo.

\footnotetext{
5 De nuevo, esta vez mediante el recurso verbal, el Celo se sitúa próximo a la figura de David, quien derribó con su honda al gigante filisteo Goliat (I Samuel, 17, 1-47).

6 Comienza a funcionar la recreación de la parábola: «El campo es el mundo. La buena semilla son los hijos del reino, y la cizaña son los hijos del maligno» (Mateo, 13, 39).

7 Cristo traza en este monólogo un resumen de la Historia Sagrada pasando por sus diferentes etapas enunciadas en tres leyes: Natural, Escrita y de Gracia. La primera de ellas abarca desde la expulsión del Paraíso hasta la figura de Moisés, la segunda desde dicho momento hasta el nacimiento de Cristo, y la última hasta la muerte del Mesías en la cruz, con la instauración de una nueva iglesia y la superación de los presupuestos escritos en el Pentateuco que regían durante la vida del patriarca hebreo.

8 Así en el original. Fíat: «Voz latina tomada en castellano para significar el consentimiento que se da para que alguna cosa tenga efecto» $(A u t)$.
} 
Celo

Cristo
¿Qué otras semillas selectas siembras?

Promesas discretas

y ley escrita también, sembrada esta por Moisén, aquellas por los profetas.

Mas aunque sembradas dejo, con más alta perfección en el humano consejo, estas leyes, al fin, son semillas de trigo añejo.

Fueron aquellas edades caducas antigüedades.

Hoy, con más firme eficacia, esparce mi ley de gracia semillas de sus verdades 50 al mundo que mando y rijo. Habló Dios de varios modos, que por sus profetas dijo.

Hoy nuevamente habla a todos, en mí, su humanado hijo'. Yo, que del paterno seno, de esplendor, de gloria lleno, soy desde mi eterna infancia imagen de su sustancia, sembrar paz al mundo ordeno ${ }^{10}$.

Ya la pasada discordia en piedad se va trocando; vuelva al mundo igual concordia, y sigan todos sembrando granos de misericordia.

9 Esta relación se sustenta en la denominación de Cristo como «hijo del hombre», la más recurrente en el Nuevo Testamento para referirse a Jesús, aunque dicha expresión se remonta al Libro de Daniel, 7, 13-14. También encontramos ejemplos más adelante: «A mí, / llámanme el hijo del hombre» (vv. 818-819).

10 Ya los profetas anunciaban el nacimiento del hijo del imperio, quien arrojará luz sobre las tinieblas: «Consejero admirable, Dios potente, Padre eterno, Príncipe de la paz» (Isaías, 9, 5).

11 Mención al regreso de los israelitas a su patria guiados por el profeta (Jeremías, 31, 1-29). Abundan en estas escenas iniciales las alusiones bíblicas puesto que se está creando el marco contextual del auto, antes de comenzar la acción dramática. Mediante este procedimiento se 
se convierta en dulce canto, pues mis dichosas andanzas siembran bienaventuranzas, dones de espíritu santo.

Fructifique mi humildad, en tierra nunca sembrada, espigas de caridad.

Celo

Esta música me agrada; cielos (si oís), escuchad.

Canta una voz buena, esta canción y sea tiple.

\section{-Canción-}

Voz del padre eterno, humanado Dios, no sois vos, Señor mío, para labrador.

Si humanos martelos ${ }^{12}$

os traen desvelado, sois muy delicado para mal de celos; vistiéndoos los cielos de rayos de sol,

no sois vos, Señor mío, \&

En tierra tan dura, ¿cómo labrar puede quien tierno procede de una virgen pura? Labrar, es ventura, ser labrado, amor.

No sois vos, Señor mío, \&

enuncia la síntesis bíblica que explique la razón de la situación en la que se encuentran los personajes, además de servir para refrescar en la mente del lector/espectador sus conocimientos sobre los hechos sagrados.

12 martelos: «La unión y correspondencia cariñosa entre dos personas» (Aut). Retrata a Cristo como enamorado del hombre y sujeto a sufrir celos porque este último prefiere otras compañías, en este caso del Mundo. 
Celo

CRISTO

Celo

Cristo

Celo

CRISTO

Celo

CRISTO

Celo
A fe que la letra tiene grande secreto encerrado.

Ser labrador y labrado ${ }^{13}$ a mí solo me conviene. Labrador soy de terrones, que mi divina palabra, a fuerza de sangre, labra 100 diamantinos corazones. Ser labrado con disgustos también me cuadra, de suerte, que ha de labrarme la muerte para dar vida a los justos.

El grano de [...]

que muerto, en tierra, al instante, ha de dar fruto abundante; siembro, y sembrándome voy.

Que muero con gusto, digo, por el hombre.

¿Hay cosecha como dar

la vida por un amigo?

Si das tu vida, Señor, justamente te ha cuadrado

ser sembrador y sembrado, ser labrado y labrador.

Ya la tierra está sembrada ${ }^{14}$, y pues trigo limpio tiene, que tú la guardes conviene.

Zagaya tengo extremada; guardarela a fe de pobre. Defiéndela de tiranos. Cultivada por tus manos ¿qué bien hay que no le sobre?

13 Dualidad en la persona de Cristo, que también puede ser concebido como sembrador y semilla de acuerdo con la parábola contenida en los evangelios: Lucas, 8, 4-15, o Mateo, 13, 1-10 (ver vv. 116-117).

14 «Salió el sembrador a sembrar su semilla. Al sembrar, una parte cayó en el camino, fue pisoteada y las aves se la comieron. Otra parte cayó en un pedregal y, nada más nacer, se secó por falta de humedad. Otra cayó entre zarzas; las zarzas crecieron y la ahogaron. Y otra cayó en tierra buena, nació y dio fruto, el ciento por uno» (Lucas, 8, 4-8). 
CRISTO Quiero a mis viñas llegar, porque a tiempo conveniente, el cachicán ${ }^{15}$ diligente las haga, amigo, cavar.

Soy labrador caudaloso

y así tener determino mi caudal en pan y vino.

Celo Puedes, como poderoso.

CRISTO Queda en paz. (Vase Cristo)

Celo Zagaya y honda

tengo. La zagaya quito, (Hincala en tierra)

y el son de la honda remito que a mis ecos corresponda. Cantaré para espantar las aves. Saldré al encuentro si entrare algún ladrón dentro. ¡Hola! ¡Hao! ${ }^{16}$ Cantar y andar.

Canta el Celo. Da voces y estalla la honda.

$$
\begin{aligned}
& \text { Ladrones que al hombre } \\
& \text { queréis hacer tiros }{ }^{17} \text {, } \\
& \text { esta vez no os cumple } \\
& \text { entrar en sus trigos; } \\
& \text { que [...] } \\
& \text { quien sembró el cortijo } \\
& \text { de esperanzas ciertas, } \\
& \text { de bienes divinos, } \\
& \text { de virtudes altas. } \\
& \text { Granos de oro hay ricos, } \\
& \text { premios de Dios grandes } \\
& \text { por trabajos chicos. } \\
& \text { Aquí todo es paz, } \\
& \text { todo afectos píos; } \\
& \text { que el ganar al hombre }
\end{aligned}
$$

cachicán: «Guarda de una finca» (DRAE).

16 iHola! ¡Hao!: ambas interjecciones con sentido vocativo. «Está corrompido de heus, adverbium vocandi» (Cov.).

17 hacer tiros: «Perjudicar, incomodar, hacer mal tercio a alguien en algún negocio o solicitud» (DRAE). 
trae a Dios perdido.

¡Hola! ¡Hao! Volad fuera aves del siglo, porque es el Celo guarda de estos trigos.

No se descubre una mosca,

y, según de claro está,

un átomo ${ }^{18}$ no vendrá

que al punto no le conozca.

Seguro está, dormir puedo

mientras mi labrador tarda,

que el campo y la viña guarda;

no la guarda sino el miedo.

¡Hola! ¡Hao! No hay enemigos;

de acogerme a dormir trato ${ }^{19}$.

(Arranca la zagaya y éntrase)

Sale el Cizañador, que es el demonio, vestido de labrador como Cristo, y prevenido como él salió a sembrar.

Cizañador

Acechando he estado un rato

a la guarda de estos trigos.

Al sembrador de esta tierra

llaman labrador del cielo

la fama, el rústico Celo,

hijos de esta inculta sierra;

siembra para hacerme guerra, trigo casto, limpio y puro.

[...]

poner su trigo de modo

que quede ahogado todo;

y yo de su pan seguro,

entresembraré cizaña ${ }^{20}$

\footnotetext{
18 En el manuscrito se lee con claridad «átamo» y así lo transcribe Imbert (1915), sin embargo no existe dicho vocablo (sin casos, por ejemplo, en CORDE), que se puede entender por «átomo», cuyo significado encaja dentro del texto, aludiendo a que la claridad de los campos será tal que cualquier visitante, por pequeño que sea, se verá descubierto por el Celo. Enmiendo la lectura errónea.

19 Se refiere a la parábola de la cizaña, junto a la del sembrador, principal sustrato argumental del auto. Una vez plantada la semilla en los campos, los hombres se disponen a descansar, momento que aprovecha el maligno para sembrar cizaña en la heredad divina (Mateo, 13, 24-30).

20 cizaña: «Hierba, y semilla, que nace entre los trigos y cebadas, muy parecida a esta en las hojas y espiga» (Aut). «A propósito de la cizaña, que en la Sagrada Escritura significa la mala doctrina y la herejía...» (Cov.). En el auto calderoniano La semilla y la cizaña opera como el personaje que representa al demonio; en el caso que nos ocupa, ese papel está representado por el Cizañador.
} 
con que su doctrina tuerza;

porque estando el trigo en huerca ${ }^{21}$,

se le consuma la saña.

Solo el barbecho de España,

que ha de oponerse, imagino,

a un Lutero, a otro Calvino;

pero cuando estos no acierten,

tengo cañas que despierten

su lascivo desatino.

Daré falsas esperanzas, y entre las misericordias

iré sembrando discordias;

contra bienaventuranzas,

sembraré vicios, mudanzas,

gustos, entretenimientos,

festines, bailes, contentos,

cuya extraña novedad

entibie su caridad,

desbarate sus intentos.

De cizaña vaya aquí;

siembro malva porque asombre

al mundo hacerse Dios hombre.

Malva, mal me va sin ti.

¿Abrojos ${ }^{22}$ no truje? Sí;

ocupen estas cortinas ${ }^{23}$.

Hombre, si a gustos te inclinas,

ven por flores de favores,

que en algún tiempo estas flores (aparte)

te parecerán espinas.

Mas que descansando duerme (mirando dentro al vestuario)

la guarda, ventura ha sido;

21 huerca: no existe en femenino, aunque probablemente es una deformación de huerco (según Covarrubias: «Este vocablo responde al nombre latino Orcus [...] Vuélvese la palabra orcus en castellano oscuridad del infierno, y tómase por el mismo infierno»), para no romper la rima. Ayuda a alcanzar esta interpretación el devastador escenario que evoca el Cizañador.

22 abrojos: «El fruto que da la planta, llamada tribulo, por las tres puntas que produce en el abrojo. Este de cualquier suerte que caiga, levanta en alto una punta aguda. Parece puede tomar origen esta palabra de Abre el ojo, por el cuidado que ha menester tener el que anda en el campo para no clavarse en ellos; y después sincopado se dijo Abrojo» (Aut).

23 cortinas: cortinal: «Un pedazo de cercado, de la palabra chortos, heno, y de aquí cortijo, porque crían en ellos la hierba o sirve de arsenal» (Cov.). 


$$
\begin{aligned}
& {[\ldots]} \\
& \text { ¿Daño pudiera hacerme } \\
& \text { que el Celo de sueño enferme } \\
& \text { y en despertar tanto tarde? } \\
& \text { Pero venga Dios y guarde } \\
& \text { el trigo con su asistencia, } \\
& \text { que en haciendo Dios ausencia } \\
& \text { cualquier criatura es cobarde. } \\
& \text { Ya esta trampa queda hecha; } \\
& \text { el descuido de sus siervos } \\
& \text { verá Dios en los acervos } \\
& \text { del trigo de su cosecha. }
\end{aligned}
$$

Hay dentro voces de fiesta e instrumentos.

$$
\begin{aligned}
& \text { Esta es, cielo, la derecha }{ }^{24} \\
& \text { contraria a tu curso pío. } \\
& \text { Holgaos hombres, que yo fío, } \\
& \text { si logro mi sementera, } \\
& \text { que presto esta primavera } \\
& \text { se os convertirá en estío. (Vase) }
\end{aligned}
$$

Salgan el Hombre y el Mundo de galanes; músicos y bailarines con ellos.

[Los Gustos] Flores olorosas, templados aires, pues el Hombre os busca, lisonjeadle.

Mil siglos te goces, Hombre, en el mundo, que los cielos se gozan de darte gusto.

Por su rey te conocen los animales, porque en bizarría no hay quien te iguale.

Tiempo tienes, Hombre, date a deleites, antes que él consuma tus años verdes.

Mundo ¿Qué te ha parecido?

HoMBre ¡Bien!

MUNDO

Huéspedes nobles, es justo que en mis tierras, a su gusto, aposentados estén;

\footnotetext{
24 derecha: derecho: «Camino o viaje derecho. Locuciones familiares con que se explica se llevan las jornadas vía recta al lugar o paraje donde se encaminan, sin extraviarse ni divertirse a otras partes» $(A u t)$.
} 
si estima hacéis de mi nombre,

Gustos, el ocio dejad

y pues veamos $[\ldots]$

en agasajar al Hombre ${ }^{25}$.

De ese monte y de sus faldas

traed calandrias ${ }^{26}$, ruiseñores;

presentes le haced de flores.

Sacrificadle guirnaldas

entre mirtos y laureles;

pase las horas dichosas,

sirvan de alfombras las rosas

de cortinas los claveles.

Dadle con mano no escasa

cuanto su gusto desea,

porque goce y porque vea

los regalos de mi casa.

MúsICOS

Vamos a servirle. (Vanse)

HOMBRE

$$
\text { ¡Oh Mundo! }
$$

$\mathrm{Tu}$ voz alienta y anima.

¿Quién tu grandeza no estima, quién de tu estilo fecundo

no se agrada? Honrarte puedes,

que de milagrosos modos

eres todo para todos,

y en todo a todos excedes.

Que vivo decir podré, que hasta haberte conocido

ni he vivido, ni he tenido

ser, que de ti lo heredé.

A ti por señor te adoro,

mis gustos te sacrifico,

y a tus aras, por ti rico,

25 La relación entre el amor al mundo y a Dios se remonta a 1 Carta de San Juan, 2, 15-17: «No améis al mundo ni lo que hay en él. Si alguno ama al mundo, el amor del Padre no está en él. Porque todo lo que hay en el mundo, las pasiones carnales, el ansia de las cosas y la arrogancia, no provienen del Padre, sino del mundo. El mundo pasa, y con él sus deseos insaciables; pero el que hace la voluntad de Dios vive para siempre». Este vínculo se traslada al auto mediante los personajes del Mundo, el Hombre y Cristo; además el dilema en el que se sitúa el Hombre será uno de los ejes de la acción dramática del texto.

calandrias: «Ave semejante a la cugujada sin el moño de la cabeza, que algunos creen poderse tener por cugujada grande, porque son parecidas en el canto, color, cabeza, alas, pies y dedos» (Aut). 
consagro víctimas de oro.

Tus heroicos hechos cante

la fama ${ }^{27}$.

Mundo

¡Oh ventura mía!

Dame esos brazos, y fía

que yo tu nombre levante

hasta la más alta esfera ${ }^{28}$.

Salen los músicos con las coronas y flores.

MúsICOS

Hombre

MúsICOS

Hombre

MúsICOS

MuNDO
Mira si gusto te dan estas diademas.

Están

gallardas.

La primavera

ha brotado flores tantas

que a dar por tributo empieza

285

lauros para tu cabeza,

jazmines para tus plantas;

parece que se va esmerando

de industria el cielo contigo.

No quiero más, cielo amigo,

que el mundo que estoy gozando.

Aristóteles afirma

que es eterno ${ }^{29}$.

\section{Cuanto ves}

en mí, obra de Dios es, y por suya lo confirma, pues dice le ha parecido bien cuanto en mí ha fabricado.

\footnotetext{
27 fama: «Los antiguos pintaron la Fama en forma de doncella que va volando por los aires con las alas tendidas y una trompeta con que va tañendo» (Cov.).

28 Se refiere al empíreo: «es el último cielo en el que se sitúa la residencia de la divinidad: "este cielo es de inmensa y inestimable luz, y de una divina claridad resplandeciente sobre humano entendimiento y capacidad, por lo cual se llama Empíreo, que quiere decir fuego; y no porque sea de naturaleza y sustancia de fuego, sino por el admirable resplandor y glorioso alumbramiento que de sí emana y procede"» (s.v. Repertorio).

29 «Aristóteles, según el fragmento 22 sacado de su libro Sobre el alma [...] decía: "Es por lo que el Mundo permanece eternamente: porque no puede ser destruido por otro ni aniquilado por sí mismo (por no contener en sí elementos de corrupción). No se encontrará ni dentro ni fuera de él otra fuerza más poderosa que ella (que su alma) capaz de destruirle”» (Bergua, 1995, p. 223).
} 
LA VERDAd (Dentro) Si no me la habéis pagado, ¿por qué os habéis atrevido a derramarme la fruta?

Uno (Dentro) Porque traéis una carga de fruta áspera y amarga ${ }^{30}$; eres labradora astuta, mas de esta vez poco medras.

¡Con esas piedras le dad!

Sale fuera la Verdad.

VERDAD

En hablándole Verdad, luego el Mundo tira piedras.

(Dentro) ¡Dale!

¡Ampárenme, señores, de esta atrevida canalla!

HOMBRE

No temas, sosiega y calla;

desecha vanos temores.

Aquí te llega a mi lado, que yo ser tu amparo quiero.

VERDAD ¡Este es el hombre primero, que la Verdad ha amparado!

HOMBRE

¿Quién te hizo mal?

VERDAD

Unos mozos,

con necia descortesía,

en la fruta que traía

y en mí han hecho mil destrozos;

echáronmela por tierra

y pisáronla. A Dios ruego

que os dé paz, vida y sosiego,

en retorno de la guerra

que me habéis dado los dos.

HOMBRE

Bien le pagas sus castigos.

VERDAD

Rogar por los enemigos

es el precepto de Dios $^{31}$.

\footnotetext{
vv. 299-302: el pasaje parte de la frase latina in aspera veritas, en relación a la frecuente crudeza de la verdad.

31 Mateo, 5, 43-45: «Sabéis que se dijo: Amarás a tu prójimo y odiarás a tu enemigo. Pero yo os digo: Amad a vuestros enemigos y rezad por los que os persiguen, para que seáis hijos de vuestro Padre celestial, que hace salir el sol sobre buenos y malos y hace llover sobre justos e injustos».
} 
Mundo

¿Qué fruta vendes? Enseña.

VERDAD

Verdades, fruta escogida

(Saca la fruta en la mano)

Mundo iQué fruta tan desabrida;

VERDAD

áspera es como una peña!

¡Jesús! ¿Qué dice, señor?

¿Hay fruta de tanto gusto

como verdad para el justo?

Mal le sabe al pecador

que decir que por su amor

se vistió de humanidad

uno de la trinidad,

$\mathrm{y}$, viendo a Dios padecer,

libro nuevo ha de hacer $^{32}$

si quisiere su amistad,

¿no es verdad?

Si el Dios que ha de ser hombre viene,

con majestad disfrazada,

en una mano la espada

y en otra la oliva tiene ${ }^{33}$;

[...]

en quietud, paz y lealtad,

$\mathrm{y}$ trata con igualdad

al grande y al pequeñuelo,

que de majestad del suelo

irá a eterna majestad,

¿no es verdad?

Si el señor, o el potentado,

porque dinero le sobre,

debiendo dar carne al pobre

él le deja descarnado,

que ni carne ni pescado

32 «Hacer libro nuevo (Por enmendar la vida y hacer mejor alguna cosa)» (Correas).

33 vv. 346-347: una de las sentencias más discutidas de Jesús: «No penséis que he venido a traer la paz al mundo; no he venido a traer la paz, sino la espada. Porque he venido a poner al hijo en contra de su padre, a la hija en contra de su madre, a la nuera en contra de la suegra» (Mateo, 10, 35-35). Aunque es bien sabido que las alusiones a la paz ofrecida por el Mesías son múltiples: «La paz os dejo, mi paz os doy; no como el mundo la da, os la doy yo. No estéis angustiados ni tengáis miedo» (Juan, 14, 27). Pero además se pueden entender estos dos símbolos en conjunto (espada y oliva), ambos incluidos en el escudo de armas de la Inquisición española, institución encargada de velar por la ortodoxia católica. En este contexto funcionaría como metáfora de la justicia divina. 
come, por necesidad

que a este Dios que es caridad,

dará su mesa y sustento

y a aquel le será tormento

su hartura y prosperidad,

¿no es verdad?

Que el buen pastor ${ }^{34}$ y prelado,

de quien Dios su iglesia fía,

ha de estar de noche y día

cuidando de su ganado

negocio es averiguado;

mas si por su flojedad

da al ganado enfermedad

de culpa y no le socorre,

que por cuenta suya corre

su pérdida y mortandad,

¿no es verdad?

Si el juez los vicios destierra

y le da en tiempo oportuno

lo que es suyo a cada uno,

¿no será sal de la tierra?

Mas si el que ha de hacerle guerra

a la mentira y la maldad

la encubre por amistad

o por $[\ldots]$

que de todo ha de dar cuenta

a otra mayor potestad,

¿no es verdad?

$\mathrm{Si}$ el regidor que gobierna

tiene con gusto y solaz

a su república en paz,

¿no es digno de fama eterna?

Mas si la piedad paterna

trueca el rigor en piedad

y anhela a falsa deidad,

vendiendo el común provecho,

34 Advocación de Cristo encargado del rebaño, símbolo de la Iglesia. Así se identifica: «Yo soy el buen pastor. El buen pastor da la vida por las ovejas [...] Tengo otras ovejas que no son de este redil. También a ellas tengo que apacentarlas. Ellas escucharán mi voz, y habrá un solo rebaño y un solo pastor» (Juan, 10, 11-16). 
que el regimiento habrá hecho

verdugo de su crueldad,

¿no es verdad?

Si el que elige religión

guardar su regla procura,

el cielo no le asegura

cambios de su salvación;

mas si allá en su reclusión

busca en vez de austeridad, gusto, oficios, vanidad,

que al fallo del mayor precio

se quedará como necio

su grave paternidad,

¿no es verdad?

Si el causídico ${ }^{35}$ letrado, de la república espejo,

cuando le piden consejo

desengaña al engañado

santo es; mas si cargado

de aurífera cantidad

tuerce la sinceridad

$[\ldots]$ pal $[\ldots]$ jus $[\ldots]$

que le dejará hecho un hurto

su avara testualidad ${ }^{36}$,

¿no es verdad?

El que excusa los galenos, que de entenderlos no trata, $\mathrm{y}$ con sus récipes ${ }^{37}$ mata más que Italia con venenos ${ }^{38}$, si echa culpa a los serenos ${ }^{39}$ $\mathrm{y}$, vendiendo habilidad,

causídico: «El abogado que trata los negocios y pleitos de las partes, solicitando y abogando por su buen despacho» $(A u t)$.

36 No encuentro la referencia, sin ejemplos en CORDE.

37 récipe: «Voz puramente latina, introducida en nuestra lengua, que significa lo mismo que receta de médico. Dícese así por empezar todas con esta voz» (Aut).

38 Los venenos como método de homicidio estaban muy extendidos por Italia durante los siglos xivxv; como buena muestra de ello puede recordarse la relación entre los Borgia y Leonardo da Vinci, encargado de experimentar con sustancias tóxicas hasta dar con un veneno que no pudiera ser percibido por el gusto, que más tarde se utilizaría por la familia italiana para ejecutar a sus enemigos.

39 sereno: «Comúnmente llamamos sereno al aire alterado de la prima noche con algún vapor que se ha levantado de la tierra» (Cov.). 
quiere encajar sanidad

a puñados de aforismos ${ }^{40}$,

que le pondrá en los abismos

su aforisma necedad,

¿no es verdad?

Y si el mercader, que vino

con empleos de importancia,

busca una justa ganancia,

para hacerse de Dios digno,

este será el buen vecino;

mas si con iniquidad

busca su comodidad

y en el dinero idolatra,

que no tendrá su mohatra ${ }^{41}$

en el cielo vecindad,

¿no es verdad?

Al decir cada una de estas coplas va sacando una fruta diferente de la cestilla que traerá en el brazo y en acabando aquella la mete y saca otra.

$\begin{array}{ll}\text { MuNDO } & \text { Verdad, mal tu vida [...] } \\ & \text { justo castigo has tenido } \\ & \text { por solo haberte metido } \\ & \text { sin causa en vidas ajenas; } \\ & \text { gentiles tus frutos son, } \\ & \text { más amargan que cicuta }{ }^{42} . \\ & \text { Gustáredes de la fruta } \\ & \text { si fuera murmuración }{ }^{43} ; \\ \text { VERDAD } & \text { mas como verdades saco, } \\ & \text { al que es del mundo confundo, } \\ & \text { porque estamos en un mundo } \\ & \text { que es grandísimo bellaco. } \\ & \text { Señores, guárdense de él. }\end{array}$

40 Alusión al excelso médico griego Hipócrates, autor de multitud de aforismos.

41 mohatra: «Es la compra fingida que se hace vendiendo el mercader a más precio del justo y teniendo en otro de manga que lo vuelva a comprar con dinero contante a menos precio» (Cov.).

42 En el manuscrito se lee «higuta», cita que no localizo, sin casos en CORDE. Considero que es errata y modifico por «cicuta».

43 Mención a Judas, 16: «Son murmuradores, descontentos, que viven conforme a sus pasiones; su boca profiere fanfarronadas, adulando a las personas con vistas a su propio interés». 
Mundo

VERDAD

HOMBRE

VERDAD

Mundo

VERDAD

Mundo

VERDAD

Mundo

HoMBre

Mundo

Pues, ¡villana! ¿En mi presencia, 455 tomas tan loca licencia?

Menos airado y cruel por su vida, que enfadado, está.

¡Calla, por tu fe! que es el Mundo.

Su merced

no será tan desosado.

¡Por quien soy! Si no estuviera puesto el Hombre entre los dos... Verdad es hija de Dios. Un pelo no me ofendiera quien se lo ve tan galán; pues a fe que por lo viejo, pudiera ser del consejo de la cámara de Adán ${ }^{44}$. ¡Calla, villana parlera! ¿Porque hablo verdades riñe?

Ya sabemos qué le tiñe: galán a la primavera, al otoño se ha de ver. Ya no lo puedo sufrir; ¡quita! maltrates a una mujer. Déjame, que yo a esa necia que haré que caro le cueste.

Sale el Celo a la puerta de su choza

Celo ¿Qué diablo de ruido es este?

44 vv. 455-479: se representa una diatriba entre el Mundo y la Verdad (puede asimilarse a una discusión entre criados de las presentes en las comedias), ambos intentando convencer al Hombre, una de que profese la fe, otro de que solo a sus gustos atienda. La Verdad se mofa de la senectud del Mundo, quien ya debía estar presente en los tiempos del primer hombre. Los términos que utiliza el autor, tanto aquí como en el caso de la relación de oficios, se pueden explicar por su profesión como relator de audiencia, puesto que se sirve de conceptos cercanos y conocidos, dotando de un toque local al asunto «eterno» del auto sacramental. 
VERDAD ¡Oh, que de galán se precia!

Pues venga el enredador

que yo lo haré.

Celo

¿En los sembrados

tanta chusma? Mis cuidados,

descuidos diré mejor,

causan este desconcierto

a galanes a quien digo

váyanse fuera del trigo,

que ya el Celo está despierto

y por vida de mi madre.

490

¡Deshacer!

Mundo Vámonos de aquí.

VERDAD Habla ahora que está allí

un criado de mi padre.

HOMBRE

¿Quién es tu padre?

VERDAD

Dios.

¿No he dicho que soy su hija?

Hombre $\quad$ Por tu gusto es bien me rija. (Lo dice al Mundo)

¿Qué haremos?

MUNDO

Vamos los dos

por este campo buscando

nuevos entretenimientos.

Hombre Glósasme los pensamientos.

Celo

Eso sí; vayan mondando

la haza ${ }^{45}$.

MUNDO

Amigos cantad.

Quédese esa con su envidia.

VERDAD Todo al Mundo le fastidia

en diciéndole Verdad.

Éntranse el Mundo y el Hombre y van cantando los músicos.

MúsICOs

Amargas verdades que al alma tocan; azucárenme el gusto dulces lisonjas.

VERDAD Tan estragado quedó

por el primero delito ${ }^{46}$

45 vv. 501-502: mondar la haza: «Desembarazar algún puesto, a semejanza del labrador cuando coge su mies» (Cov.).

46 Pérdida del Paraíso por la desobediencia de Adán; como consecuencia, todos los hombres 
el mundo que, como ahíto,

el gusto del bien perdió.

Desafusiado $^{47}$ le veo;

ya su muerte es conocida,

si Dios, que es salud y vida,

no se la da.

Celo

A lo que creo,

hablando aquí entre los dos, por causas en que me fundo, estas locuras del Mundo

le han de costar mucho a Dios;

que desde las desventuras

de Adán, obra a Dios ingrata,

este bellacón no trata

sino de hacer mil locuras.

No hay en su boca verdades,

virtud en él no aprovecha,

porque son de su cosecha

mentiras y liviandades;

todos son enredadores

sus amigos y aliados.

Sale Cristo labrador del cielo.

CRISTO

Salir a ver sus sembrados

VERDAD

es de buenos labradores.

CRISTO

$¿$ Tal gentecilla se usa, para no andar con temor?

VERDAD

¡Oh, Verdad!

A fe señor,

que todo el mundo me acusa

de necia murmuradora,

de curiosa impertinente,

de polilla de la gente,

del mundo registradora;

que afirmo lo que no sé,

que en embustes tengo mano

y que sin ser escribano

\footnotetext{
nacerían en pecado y serían culpables de este primer delito.

47 desafusiado: desafuciar: «Desahuciar» (DRAE).
} 
de todo quiero dar fe;

que soy saco de maldades,

que en mal hora acá nací,

y esto y más dicen de mí

porque digo las verdades.

CRISTO

Verdad, si verdad es Dios,

y es verdad perseguida ${ }^{48}$,

tu pena no merecida

550

padeceremos las dos.

VERDAD Padeciendo tú, será

mi persecución consuelo.

CRISTO ¿Cómo va de panes, Celo?

Celo Señor, de hoy más bien irá.

CRISTO

¿Irá dices? ¿No va bien?

Celo

Algún daño me previene.

CRISTO

Mucha yerba el trigo tiene.

¿Cizaña en mis panes? ¿Quién

ha entrado en ellos?

Celo

Señor,

viendo seguro el sembrado, me dormí, de confiado.

CRISTO Mi contrario labrador, el que es del hombre enemigo, el que a mi hechura engaña,

ha sembrado esta cizaña

entre granos de mi trigo.

Celo, a los que tienen cargos

no les conviene dormir,

que al oficio han de asistir

y velar con ojos de $\operatorname{Argos}^{49}$.

Poco celosos antojos ${ }^{50}$

importan, si se destierran

de su obligación, y cierran

48 Los judíos cuestionaban la figura de Jesús y las palabras por él predicadas. La consecuencia final de esta disputa culminará con la crucifixión del Mesías.

49 Argos: (forma latinizada) «Según unos, solo tenía un ojo; según otros, poseía cuatro, dos que miraban hacia delante y dos hacia atrás. Finalmente otras versiones le atribuyen una infinidad de órganos visuales distribuidos por todo el cuerpo» (Grimal). Biznieto del primer Argo, hijo de Zeus y Níobe; símbolo del estado vigilante.

50 antojos: «Los espejuelos que se ponen delante de la vista para alargarla a los que la tienen corta» (Cov.). 
a los peligros los ojos.

Ha de velar el pastor,

el juez ha de velar, y de su pueblo cuidar

el celoso senador; siempre debe estar en vela

el buen padre de familias ${ }^{51}$,

que contra honradas vigilias

no vale torpe cautela.

$\mathrm{Y}$ desengáñote, Celo,

que si eres guarda dormida,

cualquiera acción es perdida

en la cosecha del cielo.

Que el sueño pierdas, amigo,

otra vez es necesario,

porque no mezcle el contrario

su cizaña entre mi trigo.

Mi viña mejor está ${ }^{52}$,

pues con la labor primera,

como flor en primavera

racimos brotando está;

mas tan gallardos obreros

trabajando en ella vi,

que a los últimos les di

tanto como a los primeros;

en bondad no se le iguala

el pan que a cargo has tenido,

pues le hallo oprimido,

Celo, con yerba tan mala.

Celo

No te dé pena, Señor,

que pues nacida la vemos,

51 padre de familias: «el padre de familias era el señor de la era del sembrador divino. Este título se refiere a Dios en Mateo, 20, 1: "Simile est regnum coelorum homini patri familias, qui exiit primo mane conducere operarios in vineam suam"; cfr. también 21,33 y 13, 52; en la parábola de la cizaña de Mateo, 13, 24-30: "Simili factum est regnum caelorum homini, qui seminavit bonum semen in agro suo: cum autem dormirent homes, venit inimicus eius, et superseminavit zizania in medio tritici, et abiit. Cum autem crevisset herba, et fructum fecisset, tunc aparuerunt et zizania. Accedentes autem servi patris familias, dixerunt ei: Domine, nonne bonum semen seminasti in agro tuo?"》 (Repertorio).

52 vv. 592-599: breve alusión a la parábola de los obreros de la viña (Mateo, 20, 1-16). Se enriquece el contexto de temática agrícola integrando nuevas referencias neotestamentarias que refuerzan el argumento. 
la Verdad y yo podremos

arrancarla.

VERDAD

Por mi amor

que no se acabe en ti el gusto

con que vida al mundo das,

que en un punto la verás

610

CRISTO

desarraigada.

No es justo.

¡Tened las manos los dos!

Que si arrancarla queréis, con la mala arrancaréis

la sementera de Dios ${ }^{53}$.

Celo

¿Por qué, Señor, nos detienes?

CRISTO

Porque ya que ha hecho el daño

mi enemigo, de su engaño

he de sacar yo mil bienes;

no hagáis, mis justos, menos

620

por cortar torpes regalos,

por fuerza que haya malos

para que luzcan los buenos.

¿Si Nerones y Mezencios ${ }^{54}$

esta cizaña no diera,

625

cómo mi iglesia pudiera

tener Pedros y Laurencios ${ }^{55}$ ?

Si no dejamos espinas

de hombres tiranos crecer,

no podrá rosas haber

630

de Engracias y Catarinas ${ }^{56}$.

Que el malo vida posee

53 vv. 604-615: «Los criados fueron a decir al amo: ¿No sembraste buena semilla en tu campo? ¿Cómo es que tiene cizaña? Él les dijo: un hombre enemigo hizo esto. Los criados dijeron: ¿Quieres que vayamos a recogerla? Les contestó: ¡No! No sea que, al recoger la cizaña, arranquéis con ella el trigo. Dejad crecer juntas las dos cosas hasta la siega; en el tiempo de la siega diré a los segadores: Recoged primero la cizaña y atadla en haces para quemarla, pero el trigo recogedlo en mi granero» (Mateo, 13, 27-30).

54 Nerones y Mecencios: Nerón (emperador romano) y Mezencio (rey etrusco), modelos de gobernantes opresores y tiránicos.

55 Pedros y Laurencios: San Pedro (discípulo de Jesús de Nazaret) y San Lorenzo (mártir y diácono regionario de Roma), prototipos de buen cristiano.

56 Engracias y Catarinas: Santa Engracia de Zaragoza y Santa Catalina de Alejandría (precisamente patrona de los secretarios y taquígrafos, recuérdese el oficio de relator del autor), mártires de la Iglesia católica y buena muestra de la firmeza de fe. 
en el mundo es cosa cierta,

o para que se convierta ${ }^{57}$

o el bueno por él granjee.

635

Crezca la cizaña ahora,

que al tiempo de la cosecha, cuando menos aprovecha,

la segaréis.

Celo

En buen hora.

CRISTO

Cumple que cuidado tengas

en las cosas que te instruyo.

Ven.

Vanse Cristo, el Celo y la Verdad.

Salen el Cizañador y el Mundo.

Cizañador Pues soy príncipe tuyo ${ }^{58}$, lo que digo es bien prevengas.

Mundo Tanto estimo tu nombre,

monarca de las cóncavas cavernas,

que por servirte, al hombre, dado a regalos y delicias tiernas, mis gustos le dedico.

Pobre de bienes, si de males rico, no ha inventado deleites

la ociosidad, del apetito, vanos,

si bien dulces afeites, que no le ponga florida en sus manos,

haciéndole (aunque adusto)

brillo a los ojos y regalo al gusto.

Ya la muchacha hermosa,

gracia aparente, fealdad oculta,

poco durable rosa,

breve bien, largo mal, maleza inculta,

pena a la gloria asida,

es el alcaide de su loca vida.

\footnotetext{
57 El mal del mundo a que se alude serían los herejes y todos aquellos que no abrazan la fe católica.

58 El demonio-Cizañador se presenta como príncipe del Mundo: «para los incrédulos, cuyas inteligencias cegó el dios de este siglo para que no brille el resplandor del evangelio de la gloria de Cristo, que es imagen de Dios» (2 Corintios, 4, 4).
} 
Ya la lisonja vana, aire regalador de los oídos, con su blandura allana el primer revellín ${ }^{59}$ de los sentidos;

y allí tomando asiento

le tiraniza el ser y entendimiento.

Ya la abundante escuela

de torpes bailes, deshonestas danzas,

su cuidado desvela

venciendo en ser mudable a sus mudanzas,

donde las cabriolas

son de mis bienes inconstantes olas.

Ya el [...] ña

señuelo de sus lúgubres festines

arroja, allí acompaña

principio alegre, desastrados fines,

donde el brío porfía

vencer al mismo dueño en bizarría;

ya antes que el tiempo borre

CizañAdoR

Mundo

Hombre

CIZAÑADOR

Hombre

Cizañador

(Dentro)

(Dentro) sus años verdes, con la edad marchitos, desenfrenado corre overo $^{60}$ de sus torpes apetitos.

Derribaranle.

$$
\text { Espera; }
$$

celebrando está el vulgo su carrera.

¡El freno se ha rompido! (Dentro)

¡Procúrate arrojar!

(Otro, dentro) ¡Que te despeñas!

¡Que me valgas te pido,

mi Dios!

Mi Dios, favor me envía.

690

Parece que en la manga lo traía ${ }^{61}$.

¡Cayó! (Otro) Ya se levanta.

¿Recibiste mal?

59 revellin: «Term. de fortificación. Es una obra separada y desprendida de la fortificación, con su ángulo flanqueado y dos caras; pero sin traveses, cuyo lugar es siempre delante de las cortinas, porque su fin es cubrir la cortina y los flancos de los baluartes, y defiende las medias lunas» (Aut). overo: «Lo que es de color de huevo» $(A u t)$; equivale a «manchado», «sucio». En el original se lee «hoveros», que enmendamos en singular para concordar con el verbo y adjetivo anterior.

61 traer algo en la manga: «Tenerlo pronto y a mano» (DRAE). 
Hombre

CizañADOR

No, Dios me ha librado.

De confianza tanta

reniego. (Dentro) Agua le den.

CizañAdor

¡Hase escapado!

HOMBRE

Ya he cobrado el aliento.

Cizañador

Nunca pude con él lograr mi intento.

Mundo, tú le visita;

quizá tendrás más próspera fortuna,

y a mi amistad le incita.

Mundo

No dejaré por ti ocasión ninguna

que no intente, hasta darte,

como de mí, también del Hombre parte.

Cizañador Yo sigo otro camino

en tanto que con dádivas le tornas

al primer desatino,

y con nuevos deleites le sobornas.

Mundo

Hacia acá viene; vete,

que asiré la ocasión por el copete ${ }^{62}$.

Cizañador

No me apartaré lejos,

breve será mi mal sufrida ausencia

si guarda tus consejos:

segura tiene de mi horror la herencia.

Mundo

Valdrame tu cautela.

CIZAÑADOR

El odio que le tengo me desvela.

Sale el Hombre y con él los gustos, que son los músicos.

HOMBRE

Vime a peligro de muerte

y escapé.

MúsICOS

¡Ventura ha sido!

Mundo

De brioso y atrevido,

casi pudieras perderte.

Gustos y entretenimientos

tengo yo con que servirte,

62 copete: «Asir o coger la ocasión por el copete. Es aprovecharse y valerse de ella en oportunidad y tiempo, sin malograrla» (Aut). «La ocasión asilla por el copete o guedejón. (Pintaron los antiguos la ocasión los pies con alas, y puesta sobre una rueda, y un cuchillo en la mano el corte adelante, como que va cortando por donde vuela; todo denota su ligereza, y con todo el cabello de la media cabeza adelante echado sobre la frente, y la otra media de atrás rasa, dando a entender que al punto que llega se ha de asir de la melena, porque en pasándose la ocasión no hay por dónde asirla)» (Correas). 
sin procurar divertirte

en peligrosos eventos.

¿Estás lastimado?

HOMBRE

No;

y si acaso lo estuviera,

tu vista salud me diera.

Mundo Mi fortuna te ayudó;

quiérote bien y procuro

que aun el aire no te ofenda.

HOMBRE

Si de mí te he hecho ofrenda,

está de mi amor seguro.

Mundo Pues pesadumbre no sientes,

ya que entre flores estamos,

los dos nos entretengamos

con festines diferentes.

¿Quieres música?

HOMBRE

No.

MUNDO

¿Quieres

bailes que el gusto entretengan?

Hombre Deja bailes, naipes vengan.

Juguemos si tahúr eres.

Mundo Ganarte he.

HOMBRE

Perder contigo

será florida ganancia.

Mundo Apacible es esta estancia, y solo tu gusto sigo.

¡Mesa y naipes!

HOMBRE

Dime, Mundo,

¿Qué es lo que se ha de jugar?

Mundo $\quad$ Largo $^{63}$, si quieres ganar; y advierte...

Hablan entre sí aparte pasando los naipes como que juegan pintas conversando. Salen Cristo, la Verdad y el Celo.

CRISTO

Mi intento fundo

en dar libertad al hombre

del yugo de estos tiranos.

63 largo: «Vale también dilatado, mucho y continuo» $(A u t)$. 
VERDAD

Es hechura de tus manos

y ensalzador de tu nombre,

por quien es y por quien eres

no has de permitir, Señor,

que un fingido labrador,

falso como sus placeres,

755

la estampa de Dios destruya;

y como Nembrot ${ }^{64}$ triunfante

a tu pesar se levante

con el que es hechura tuya.

CRISTO

Téngole grande afición

y voy su bien procurando.

Celo Con el Mundo está jugando;

llegas a mala ocasión.

CRISTO Mi auxilio tiene presente,

Celo, y aunque es de él capaz,

si no le fuere eficaz

de mi parte, es suficiente

ponga él de la suya.

Celo

CRISTO

¿Qué?

Dolor que su error matice;

porque aunque sin él lo hice

sin él no le salvaré ${ }^{65}$.

Han de juntar, no te asombre,

aunque no con parte igual,

el Hombre y Dios su caudal

porque halle ganancia el Hombre.

775

Celo Entre deleites injustos, ¿qué bien se puede esperar de él?

CRISTO

Yo le he de ganar,

Celo, con sus propios gustos;

las cautelas más discretas

que hay, advierte lo que digo,

son dar mate al enemigo

64 Nembrot: Nemrod: rey de Mesopotamia, construyó la torre de Babel.

65 vv. 769-771: sobre la creación del hombre: «Dios dijo: "Hagamos al hombre a nuestra imagen y semejanza. Domine sobre los peces del mar, las aves del cielo, los ganados, las fieras campestres y los reptiles de la tierra"» (Génesis, 1, 26). Sin embargo, es necesaria su adhesión a la fe para que consiga salvarse y redimirse del pecado de Adán. 
con sus armas y sus tretas.

A Adán venció por comer, yo con comer le rescato ${ }^{66}$;

placer da al hombre, y yo trato

de ganarle con placer.

Hoy al cielo y a la tierra, mostrar mi potencia quiero;

que es Dios maná ${ }^{67}$ verdadero

que todos gustos encierra.

Juegos no le dan lugar

para que de mí se acuerde,

y pues jugando se pierde,

jugando lo he de ganar.

Hoy he de alcanzar la palma ${ }^{68}$

del que mi muerte previene,

que juegos la Iglesia tiene

con que se entretiene la alma.

Propio es de los labradores

holgarse, mientras que llega

el tiempo para la siega;

démosle al hombre favores.

Llego.

Hombre

¡Suertes venturosas!

Si hubiera interés jugado,

mucho te hubiera ganado,

Mundo.

Mundo

Aventurar no osas

tu caudal.

HOMBRE

Quiero contigo

jugar un grande interés.

CRISTO

Si un tercio ${ }^{69}$ menester es,

no podrá faltar.

66 Cristo es el pan de vida, que mediante la Eucaristía satisface al alma humana: «Jesús les dijo: "Yo soy el pan de la vida. El que viene a mí no tendrá hambre y el que cree en mí no tendrá sed jamás"» (Juan, 6, 35).

67 maná: alimento enviado por Dios al pueblo de Israel durante su travesía por el desierto. Se utiliza asimismo como símbolo de la Eucaristía.

68 palma: «Se toma también por la insignia del triunfo y la victoria, porque los romanos coronaban con palma a los victoriosos: y figuradamente se toma por el mismo triunfo, y se extiende a otras materias: y así se dice la palma del martirio, y se pone por insignia de la perpetua virginidad» $(A u t)$.

69 Tercer jugador, Cristo se une a la partida de naipes. 
Mundo

Cristo

Mundo

CRISTO

HoMBre

CRISTO

HOMBRE

CRISTO

HoMBre

CRISTO

Mundo

CRISTO

Mundo

CRISTO
Amigo,

¿sois jugador?

Razonable.

Juguemos, si tercias vos.

Jugado habemos los dos

algunas veces.

¡Notable

815

presencia! Decid el nombre.

¿Impórtaos saberlo?

Sí;

que me aficionáis.

A mí,

llámanme el hijo del hombre,

y aunque otro país mejor

820

que éste mi linaje encierra,

me avecindé en esta tierra ${ }^{70}$

porque a vos os tengo amor;

y desde que alcancé a veros

en este ameno lugar,

825

con los dos deseo jugar

solo por entreteneros.

Mil gracias por ello os doy,

que en extremo me obligáis,

señor.

Siempre que queráis,

830

a vuestro mandado estoy.

Antes que el juego empecemos, ¿queréis tomar un bocado?

Algo llego fatigado;

sí, tomaré.

Bien tenemos

835

que dar. ¡Hola! ¡Cajas!

No;

eso es para vos decente,

que coméis curiosamente;

pan y vino quiero yo,

que a mí un bocado me basta ${ }^{71}$.

70 vv. 821-822: el linaje de Jesús se sitúa en Israel mientras que el contexto del auto se supone en España.

71 vv. 839-840: aunque es conocida la frugalidad de Cristo, el bocado se refiere a la hostia, en una situación que recrea la Última Cena del Señor con los apóstoles. 
Saquen los músicos una mesica con sus manteles y un panecico y una copa de vino con sus salvillas.

MúsICOS

Aquí el pan y el vino están.

CRISTO

La substancia de este pan

cielos y tierra contrasta.

Atended a esto: en el nombre

de mi padre, en quien confío,

845

este pan, el cuerpo mío

es. Llega y prueba de él, Hombre.

El cáliz es este, advierte,

de mi sangre que, colmado,

por ti será derramado

850

y por muchos con mi muerte.

Come, Hombre, de este manjar

que a los ángeles admira,

mas si lo gustares, mira

que en gracia se ha de llegar,

855

que es en extremo tan fuerte

la virtud de esta comida

que, estando en gracia, da vida

y en pecado, causa muerte ${ }^{72}$.

Hombre Gran Señor, yo no me atrevo

CRISTO

a engolfarme ${ }^{73}$ en ese abismo.

Yo como mi cuerpo mismo,

y mi propia sangre bebo,

(Levantándose de donde comía)

conque ya más alentado, entraré, Mundo, en tu juego.

Mundo

¿Qué has hecho y dicho?

CRISTO

Estás ciego,

MuNDO

y este bien no has penetrado.

¿Tu cuerpo este pan, Señor?

¿Tu sangre este vino? Di.

72 «Por eso, el que come del pan o bebe del cáliz del Señor indignamente será reo del cuerpo y de la sangre del Señor. Por tanto, examine cada uno su propia conciencia, y entonces coma del pan y beba del cáliz. Porque el que come y bebe sin considerar que se trata del cuerpo del Señor, come y bebe su propia condenación» (1 Corintios, 11, 27-28).

73 engolfarme: engolfarse: «Término náutico; cuando las galeras u otros bajeles dejan de ir tierra a tierra y se meten en el golfo, atravesándole por donde no ven otro que agua y cielo» (Cov.). 
CRISTO

Mundo

CRISTO

HOMBRE

Mundo

HOMBre

CizAÑADOR

Muerte

CIZAÑADOR
CRISTO

VERDAD

Celo
No se engasta bien en ti

piedra de tanto valor.

Creer lo que no se ve

es fe, y si buscas su aumento, cautiva tu entendimiento

en servicio de la fe.

Entiendo menos ahora.

Cuanto especulares más, menos, Mundo, entenderás.

$\mathrm{Su}$ discreción enamora.

Deja eso, juega y baraja.

Hoy seré de buena suerte.

De vencida vamos, Muerte,

(A la Muerte)

si este juego no se ataja.

Siendo robado el partido

no des al juego lugar.

Con los dos no has de jugar,

(tómales los naipes)

que eres tahúr conocido, que si las cartas conoces, en juego tan desigual

los dejaras sin caudal

y meterlo has todo a voces ${ }^{74}$.

Es mandria ${ }^{75}$ el hombre, es cuitado,

polilla de su hacienda.

¡Juega tú con quien te entienda

las tretas que has siempre usado!

¡A ver qué ganancia llevas!

Arrogante ${ }^{76}$ tahúr eres.

Sin juicio estás, pues que quieres

hacer con él bazas nuevas.

Volverá descalabrado

900

\footnotetext{
74 meterlo has todo a voces: meter a voces: «Confundir y ofuscar la razón metiendo bulla» $(D R A E)$.

75 mandria: «El hombre de poco ánimo y espíritu, que se acobarda y no tiene valor para resistir a otro» $(A u t)$.

76 La soberbia es una característica prototípica del demonio; fue por ello que perdió el favor divino y descendió a los infiernos (Isaías, 14, 12-15).
} 
CRISTO Yo contigo jugar quiero, pues tu hora ha llegado.

Cizañador

CRISTO

CiZAÑADOR ¿Y a qué habemos de jugar?

CIZAÑADOR

VERDAD ¡Al hombre ${ }^{77}$, pues yo lo soy!

Mal con ese juego estoy, porque no puede llegar ocasión que yo hombre sea.

CizAÑADOR De esa ventura estás falto.

VERDAD

Loca, yo pico más alto.

Celo

CizaÑADOR

Bueno.

Luzbel, devanea.

Sin juicio estáis los dos, en dar al juego ese nombre; juegue ese al juego del hombre, yo juego al juego de Dios.

Celo ¡Calla, vil!

CIzAÑador

CRISTO

Cizañador

CRISTO

Cizañador

CRISTO
De juego vaya.

¿Ha de haber tramoyas ${ }^{78}$ ? No;

que en tus tramoyas sé yo que no hay tahúr que no caiga.

Luzbel, llano ${ }^{79}$ ha de ir al juego.

Algo esta llaneza anuncia $\mathrm{y}$ repone quien renuncia.

Repone vida y sosiego el que el bien, que es celestial tesoro de amor profundo, 925 renuncia por el del mundo, caduco y débil caudal. ¿Quién jugará? ¿El Mundo?

que en el juego que hoy prosigo jugará el Mundo conmigo, 930

\footnotetext{
77 juego del hombre: «Género de juego de naipes entre varias personas con elección de palo, que sea triunfo, y el que la elige se llama hombre. [La forma] Más principal y antigua es la que llaman Renegado y se juega entre tres, dando a cada uno nueve cartas, y el que tiene juego entra eligiendo triunfo y para sacar la polla necesita de cinco bazas» (Aut).

78 tramoya: «Metafóricamente vale enredo hecho con ardid y maña, o apariencia de bondad» $(A u t)$.

79 llano: «Se toma también por afable, apacible, y que no usa de su autoridad y gravedad con los otros» $(A u t)$.
} 
CizAÑADOR

Mundo

CRISTO

CizAÑADOR

CRISTO

MuerTE

HOMBRE

CRISTO

CIZAÑADOR

CRISTO
Tres jugadores estamos.

¿Quién será el cuarto?
La Muerte
que también ha de hacer suerte
en mí.

Pues a jugar vamos.

935

Hoy, por ensalzar tu nombre,

(Al Hombre) Hombre, me veré afrentar,

que es el que voy a jugar

el propio juego del hombre.

Vengan naipes.

(Saca unos naipes la Muerte)

buenos.

Estos son

940

traen.

Pinturas distintas

Hombre, son estas pintas

dibujos de mi pasión.

Discreta, Muerte, has andado

en medio de tu locura,

945

pues el cáliz de amargura ${ }^{80}$

me le ofreces disfrazado

en juego del que se ha hecho

hombre por el Hombre. Ven

a jugar.

Pues mira bien

950

los naipes.

Ya yo lo he hecho.

¿Quieres que por los dos juegue?

Esto con el Hombre aparte. Hablan entre sí los otros jugadores aparte.

Hombre ¿En juego que han de afrentarte, me quieres a mí dar parte?

Cristo Cuando yo a ese punto llegue, ¡aunque la muerte me asombre, cumple, vaya por los dos,

\footnotetext{
80 Pasaje bíblico que se encuentra después del anuncio de la condena a muerte de Cristo hecho por sí mismo a sus apóstoles; alude a la penitencia que deberá pasar para conseguir la Redención humana.
} 
porque pasiones de Dios

son regalos para el hombre!

Hombre Yo no tengo caudal.

CRISTO

No.

960

Hombre

Son muy cortos mis haberes.

CRISTO

HOMBRE

Pon, Hombre, lo que pudieres,

que lo demás pondré yo.

CRISTO

¿Qué pondré?

CRIsto

HOMBRE

Si yo por ti

hago de mi vida empleo,

965

pon tú siquiera el deseo

de dar la tuya por mí;

pon un ay de contrición,

un dolor arrepentido

de haber a Dios ofendido,

que estos tus caudales son;

un odio del mundo loco,

un amor al bien eterno,

un sí de tu pecho tierno,

que aunque esto todo es tan poco,

975

con mi sangre lo acredito

por modo tan celestial

que el tuyo con mi caudal

un todo hará infinito;

y cuando Luzbel arguya

tu vida por alevosa, madre tengo yo piadosa, que será abogada ${ }^{81}$ tuya.

Todo mi caudal te ofrezco;

Señor, juega por los dos

y mereceré por Dios

lo que por mí no merezco.

CRISTO Ya voy a jugar gustoso;

tomo asiento. (Siéntase Cristo)

CiZAÑ̃DOR

Y yo también.

Quitale el Celo el asiento al Cizañador y hácelo sentar en el suelo.

$\overline{81}$ Está extendida la idea de que la Virgen ejerce como abogada y mediadora entre el hombre y Dios, aunque no existe ningún escrito que lo atestigüe, ni se encuentran casos en la Biblia. 
Celo

CiZAÑADOR

Celo

VERDAD

Cizañador

VERDAD

Celo

Cizañador

VERDAD

Mundo

Celo

CizaÑADOR

CRISTO

Mundo

CRISTO

Cizañador

CRISTO

MUERTE

HOMBRE

CRISTO

VERDAD
¡Descomedido, detén!

990

Siempre has de ser envidioso.

Tu desvergüenza atrevida merece esta afrenta.

¿no te bastó la primera, sin dar segunda caída?

¡Pesia! ${ }^{82}$

Calla, fanfarrón.

Menos brío.

Esto consiento.

¿Los dos no tomáis asiento?

Nuestras rodillas lo son.

Discretos habéis andado;

1000

humíllate tú, mestizo.

A pesar de quien me hizo

ya estoy, villano, humillado.

¿Qué polla ${ }^{83}$ se pone?

Yo

pongo la honra en que me fundo.

1005

Poca cosa honra del Mundo.

Yo mi poder.

Tuyo no.

El que tienes, bestia fiera, te le da el Dios de Jacob ${ }^{84}$, que no ofendieras tú a Job ${ }^{85}$ 1010 si licencia no te diera. Yo pongo los triunfos todos que esta guadaña ha ganado. Brava polla se ha juntado. Todos, por diversos modos, puesto habéis vuestros caudales, mas yo pongo el de mi vida.

La ventaja es conocida.

82 pesia: «Para expresar desazón o enfado» (DRAE).

83 polla: «En algunos juegos de naipes, puesta (cantidad que pone el que pierde para disputarla en la mano siguiente)» $(D R A E)$.

$84 \mathrm{Jacob}$ : descendiente de Abrahán y patriarca bíblico.

85 No encuentro alusión alguna a la ofensa de Job, por lo que el personaje pudo ser elegido en este pasaje para continuar la rima, por otro lado difícil, con Jacob. Es posible que quiera expresar lo mismo que el refrán: «No ofende quien quiere sino quien puede» (referido al demonio). 
Cizañador De mi daño veo señales

si este el hijo de Dios es;

1020

pero creerlo no quiero.

¿No es hijo de un carpintero?

Mundo, alerta es bien estés.

Alzo a la mayor, ve espadas.

Mundo El siete me ha entrado.

CRISTO

Dar

1025

puedes mano.

Mundo

¿He de robar?

CRISTO

VERDAD

Mundo

CRISTO

(Cantan)

Siempre de robar te agradas.

Mira este exceso de amor,

Hombre, pues por tu sosiego,

desde aquí comienza el juego

1030

de su pasión el Señor;

sus penas, sus agonías,

entre sufrimiento santo,

que en ellas principia el llanto

de sus trenos ${ }^{86}$ Jeremías.

1035

De copas triunfo ha salido

carta blanca ${ }^{87}$, algo sospecho.

Celo y Verdad, de mi pecho,

que nos cantéis algo os pido.

(Cántele un coro)

El hijo del padre eterno,

1040

el que de los cielos altos

bajó a ser hombre a la tierra,

juntando extremos contrarios,

con Luzbel, con Mundo y Muerte

juega al hombre, por sacarlo

1045

del Argel de los abismos,

ladronera de corsarios ${ }^{88}$.

(Otro CORO) Puestos están frente a frente

los dos valerosos campos,

el de Dios y el de Luzbel,

86 trenos: «Cada una de las lamentaciones del profeta Jeremías» (DRAE); estas manifestaciones anímicas son constantes en sus escritos.

87 carta blanca: «En el juego de los naipes es no tener en todas ellas el que juega ninguna figura del rey, caballo o sota, sino todas de cuatros, seises y otras semejantes» $(A u t)$.

88 vv. 1046-1047: es conocida la actividad de piratería llevada a cabo por los corsarios musulmanes en el norte de África. 
Señor justo y siervo ingrato;

para comenzar sus lides

escaramuzan jugando.

(EL OTRO CORO) ¡Lo que a los ojos son cartas

son al dar el golpe rayos!

1055

CRISTO

Vamos oros, Mundo.

Mundo

CRISTO

Juega (Como que no quiere ir a oro)

¿Del partido haces desprecio?

¡Pues hombre soy, hombre digo!

Cizañador Morirás, si hombre te has hecho.

Cristo Juego de mano el tres de bastos,

1060

de Diego, de Juan y de Pedro,

que viéndome en la oración,

se durmieron en el huerto ${ }^{89}$.

Muerte ¡Como leños se quedaron!

Ese seis de espadas juego.

1065

CizañAdor

Yo el seis de bastos.

VERDAD

contra un humilde cordero?

Mundo Echo el cuatro de los palos

que sirven de puente al huerto

por el arroyo Cedrón ${ }^{90}$.

1070

Cizañador La primera baza he hecho. (Primera baza del demonio)

Sota de oros juego, gano.

Mundo

Yo echo el seis.

CRISTO

Oros no tengo;

que yo siempre estoy baldado

de ese manjar de soberbios.

1075

Fuerza es que con copas gane.

Juego el cuatro de los premios

que recibirán los justos

comiendo en gracia mi cuerpo:

suavidad, solaz, hartura,

1080

con un espíritu interno

inflamado en caridad

89 vv. 1061-1063: «[Jesús] Se levantó de la oración, fue a sus discípulos y los encontró dormidos por la tristeza. Y les dijo: “PPor qué dormís? Levantaos y orad para que no caigáis en la tentación”» (Lucas, 22, 46).

90 Cedrón: arroyo en Jerusalén que da nombre al valle y cercano al Monte de los Olivos, donde prendieron a Jesús (Juan, 18, 1-11). 
que al hombre le hace un Dios nuevo, no como aquel desdichado

a quien hoy le di mi cuerpo

1085

Muerte

CRISTO

MuerTe

CRISTO

y me pagó con venderme

las mercedes que le he hecho.

Cinco oros va.

seis por cinco.

Multiplica

Treinta han hecho.

Ese es el precio en que Judas

1090

me vendió a los Fariseos ${ }^{91}$. (Coge Cristo esta baza)

Gané; juego el dos espadas

de dos cuchillos que veo

que mis discípulos tienen.

CizAÑAdor

¿No les mandaste tú a ellos,

que las túnicas vendiesen

para comprarlos?

CRISTO

Misterios

tan profundos no se ajustan,

Luzbel, a tu entendimiento;

eres doctor ignorante ${ }^{92}$.

MUERTE Yo juego el cinco, que quiero

que contra ti sobren armas.

CIZAÑADOR Con la sota ${ }^{93}$ ganar quiero,

de la sinagoga ingrata,

que de tu vida haciendo

escarnio para prenderte, (Segunda baza del demonio)

91 vv. 1089-1091: Judas Iscariote vendió a Jesús por treinta monedas de plata.

92 Sobre la inteligencia del demonio: «según San Isidoro (Etimologías, L, VIII, cap. XI, 15-16) "Demonio, del griego daemonas, significa perito, sabedor de cosas. Conoce muchas cosas futuras, por lo que suele dar algunas respuestas de lo porvenir. Existe en ello un mayor conocimiento de las cosas que el que es dado a la humana flaqueza, debido en parte a mayor agudeza de entendimiento, en parte a la experiencia de su larga vida («Más sabe el demonio por viejo que por demonio» dice el refrán), y en parte por revelación angélica, según el mandato de Dios». Por su rebelión, los demonios perdieron a Dios pero no sus cualidades excelsas de inteligencia; por ello según Santo Tomás, a pesar de su caída, tienen ciencia profunda y su luz intelectual es perspicaz (Summa, I, 64, 1). En el entendimiento de los demonios solo cabe error respecto de las cosas sobrenaturales (id., 58, 5)» (Repertorio); de ahí que se les escape el misterio de la fe, la transustanciación y la humanidad de Cristo.

93 sota: «Suele tener una connotación negativa, representando más bien a la mujer venal» (Cov.). Se relaciona con la sinagoga, metonimia del pueblo judío, responsable en los autos de la muerte de Cristo, aunque esta versión contraste con los escritos bíblicos que describen cómo dicha acción fue ejecutada por los centuriones romanos. 
previno armas y dineros.

(Coge esta baza el Cizañador)

Triunfo con el tres de copas;

Cristo, turbado te veo.

CRISTO Agonías de la muerte, me dan.

CIZAÑADOR

MuNDO

CRISTO

VERDAD

CiZAÑ̃doR

CRISTO
Larga, Mundo.

Echo

el rey de oros. Voyme de él, que ya que copas no tengo no quiero hacer daño.

si es posible, yo te ruego

que pases de mí este cáliz ${ }^{94}$ !

Verdad, canta, canta presto.

Tristis est anima mea

usque ad mortem ${ }^{95}$.

Gano el resto

si esta baza gano.

Aguarda,

que con la música he vuelto

sobre mí. Tu voluntad

se haga, no lo que yo quiero.

Con el dos gano esta baza,

porque si como hombre temo

esta voluntad humana,

a la divina sujeto;

que el dos son dos voluntades,

divina y humana, advierto,

pero venció la divina

al bien del hombre atendiendo.

(Coge la baza Cristo)

Vuelvo otra vez por espadas

que me persiguen hoy; juego

el cuatro.

MUERTE

De oros me voy.

\footnotetext{
94 «Él [Cristo] se apartó de ellos como un tiro de piedra, se arrodilló se puso a orar, diciendo: "Padre, si quieres, aleja de mí este cáliz, pero no se haga mi voluntad sino la tuya"» (Lucas, 22, 41-42).

95 vv. 1118-1119: «Me muero de tristeza, quedaos aquí y velad conmigo» (Marcos, 14, 34).
} 
CIZAÑADOR

Al perdido bastos juego,

de los que serán azotes

de tu carne, de tu cuerpo;

mas esa es carta perdida,

pues que no me es de provecho,

pero verás convertida

esta polla en gallo presto,

despertador de tus penas,

como en su canto de Pedro.

Mundo Yo gano aquí con el siete, (Primera baza del Mundo) ¡tengo una baza!

Cristo

Y yo tengo

1145

fija esta baza en el alma,

porque en ese siete veo

los dolores de mi madre ${ }^{96}$,

en cuyas puntas contemplo

clavado su corazón

del dolor de mi tormento.

Mundo Oros juego.

CRISTO

Yo el as de copas

Muerte $\quad$ Estoy baldada y sin triunfo;

bastos juego.

CIZAÑADOR

Yo los tengo.

1155

El caballo me has sacado,

que he ensillado para el ciego

que te ha de hacer un gran tiro.

CRISTO Yo estoy a todo dispuesto.

(Coge Cristo la baza)

Con Herodes ${ }^{97}$, rey de copas,

arrastro, que loco y necio,

embriagado de sus vicios

hace de mí menosprecio.

MuerTe

Bastos echo. Luzbel gane,

porque yo copas no tengo.

${ }^{6}$ vv. 1147-1148: advocación de la Mater Dolorosa, así denominada por los siete dolores que la Virgen sufrió en su vida, muchos de ellos durante el momento bíblico que se está recreando.

97 Herodes: ordenó la Matanza de los Inocentes para acabar con la vida de Jesús niño, lo que obligó a José y María a emprender la huida a Egipto. 


\begin{tabular}{|c|c|c|}
\hline CIZAÑADOR & $\begin{array}{l}\text { Yo gano con la malilla }{ }^{98} \\
\text { de mis cautelas y enredos. }\end{array}$ & \\
\hline Mundo & No tengo triunfo. & \\
\hline \multirow[t]{2}{*}{ CIZAÑADOR } & Tres bazas & \\
\hline & $\begin{array}{l}\text { hay seguras por lo menos. } \\
\text { A reposición me huele } \\
\text { esta polla. }\end{array}$ & 1170 \\
\hline CRISTO & Calla necio. & \\
\hline CIZAÑADOR & $\begin{array}{l}\text { Juego el caballo de bastos, } \\
\text { brioso, tascante, fiero, } \\
\text { que saca el centurión. }\end{array}$ & \\
\hline HoMBRE & ¿Para qué? & \\
\hline \multirow[t]{6}{*}{ CiZAÑADOR } & $\begin{array}{l}\text { ¿No oyes los ecos } \\
\text { que retumban crucifique? }\end{array}$ & 1175 \\
\hline & Los juncos marinos tiesos & \\
\hline & que le coronan, ¿no ves? & \\
\hline & ¿No ves la caña por cetro? & \\
\hline & ¿La venda que por los ojos ${ }^{99}$ & 1180 \\
\hline & la culpa le está poniendo? & \\
\hline VERDAD & No la suya, de los hombres. & \\
\hline CIZAÑADOR & ¿No ves? & \\
\hline CRISTO & El basto atravieso & \\
\hline & $\begin{array}{l}\text { de la cruz que me da el mundo; } \\
\text { pesada carga sustento, } \\
\text { mas ¡con él gano la baza! }\end{array}$ & 1185 \\
\hline
\end{tabular}

Echa luego en echando Cristo el basto la Muerte una carta.

CiZAÑAdor

MUERTE

CRISTO
¡Gana, Muerte, gana!

a jugar.

Vuelvo

¡Ten! Ya has jugado

carta de bastos.

\footnotetext{
98 malilla: «En algunos juegos de naipes, carta que forma parte del estuche y es la segunda entre las de más valor. En oros y copas, se toma el siete por malilla, y en espadas y bastos, el dos» (DRAE).

99 vv. 1175-1180: el pueblo judío, instigado por los sumos sacerdotes, pedían a gritos la crucifixión de Cristo; entonces, la guardia de Herodes le lleva al palacio, le viste una túnica, le impone una corona de espinas y un cendal en los ojos mientras se burlan de él y lo azotan (Marcos, 15, 16-20).
} 
Cizañador

¡El cielo

solo conmigo podía

hacer este desconcierto!

MuerTe

Gran virtud tiene este basto.

¡Oh poderoso madero

que me hace temblar!

CRISTO

Cansado

me hallo con tanto peso.

¿Hay quien un trago de vino

me dé porque cobre aliento? ${ }^{100}$

Hombre Vesle aquí, Señor famoso.

CRISTO Mirado está, no le quiero.

Cuatro y tres bazas estamos.

La sota de copas tengo,

de las hijas de Sion,

que tristes me van siguiendo.

Juégola.

CIZAÑADOR

No ganes, Muerte.

Muerte

Dejar de ganar no puedo,

Luzbel, tengo la espadilla.

CIZAÑADOR

¡Trágala, pesia a tus huesos!

que gano con el caballo

de mi obstinación.

MuerTe

Perdemos,

pero por morir con honra

por dicha mi daño tengo.

Por tu malicia, Luzbel,

en el mundo tengo imperio

sobre todos los mortales,

y pues mortal Dios se ha hecho,

contra él he de ejecutar

el rigor de mis preceptos

$\mathrm{y}$, aunque sea a costa mía,

muera Cristo. Luzbel, juego

la espada de mi guadaña.

Recibe este golpe recio,

reparador de la vida,

y muere tú pues me has muerto.

100 vv. 1196-1197: durante el periplo por el Gólgota, Jesús pidió vino y le ofrecieron la bebida mezclada con hiel, por lo que después de probarla no la bebió (Mateo, 27, 33-34). 
Levanta la guadaña y tiénela en alto temblando.

No puedo.

CRISTO

¿Desmayas loca?

Pues a costa de mi pecho

hoy, Muerte, seré tu muerte,

tu bocado seré, infierno.

Llegar puedes.

MUERTE

¡Maté Cristo!

Cristo Conque diste fin al juego,

gané; mi espíritu, padre,

en tus manos encomiendo.

Va subiendo Cristo por la cruz y cúbrele una nube $e^{101}$.

Canten a modo de endecha.

¡Llorad cielos,

que el autor de la vida, habida, es muerto!

Hay dentro mucho estruendo y golpes

HOMBRE

Ya diste a tu padre la alma

divino Señor, ¿qué es esto?

1235

¿Qué noche cubre la tierra?

¿Qué relámpagos y truenos,

la cuarta esfera ${ }^{102}$ vomita?

VERDAD ¡De los sepulcros abiertos

salen los muertos clamando;

las piedras se dan encuentros!

CizañAdor

¡Ah Muerte, indiscreta y loca!

¡Harto te avisé en los sueños

de la mujer de Pilatos ${ }^{103}$ !

MUERTE

Luzbel, no pude hacer menos;

llamome y obedecile.

101 «Desde el mediodía se oscureció toda la tierra hasta las tres de la tarde» (Mateo, 27, 45).

102 El sol, según la división de las esferas ofrecida por Dante en la Divina Comedia.

103 Percibió en sueños la injusticia que estaba a punto de cometerse con Cristo, puesto que no era culpable de los delitos que se le imputaban. 
Mundo

Celo

HOMBRE
Hijo de Dios verdadero

es este; león de Judá ${ }^{104}$.

Y de Baptista el cordero ${ }^{105}$.

Ojos, deshaceos en llanto,

que si en el sepulcro muerto

está quien os dio la vida, haced del sepulcro centro y allí os enterrad con él.

Culpas, que grillos y hierros

tenéis puestos en mi alma,

dejadme; ya es otro tiempo,

ya la noche de mi error

que tanto me tuvo preso,

pasó. Ya amanece el alba

1260

de mis propósitos nuevos.

Virgen, como luna hermosa,

si del sol del hijo vuestro

sentís ausencia tan larga,

justo es vuestro sentimiento,

CElo Dame albricias, Hombre, el cielo

se aclara, ya sale el sol;

la luna en frente se ha puesto.

Parece Cristo glorioso en la cruz. En una mano una hostia muy grande, en la otra un cáliz. Desde la hostia al suelo hay espigas de trigo, y abajo, pajas largas con espigas, como sembrado. Desde el cáliz hay pámpanos hasta abajo y en el tablado abra desde aquellos pámpanos y sarmientos un pedazo como viña. Está el Cristo cercado de rayos y otra cerca más afuera, como la del toisón, que serán naipes eslabonados y pintados en ellos los instrumentos de la pasión, y pendiente bajo de los pies del Cristo, donde se ha de rematar, estará un cordero degollado. En la parte frontera, en el otro vestuario del coro, estará la Virgen María, cercada de rayos, el dragón a los pies ${ }^{106}$ y puesta sobre una luna grande en medio del tablado.

104 león de Judá: «La expresión procede de Génesis, 49, 9 ("cachorro de león es Judá") y es la bendición que Jacob da a su hijo Judá, que fundará la tribu de donde ha de venir el Mesías (Isaías, 11, 1). La concreta aplicación a Cristo de este título la hace Apocalipsis, 5, 5: "No llores; ha triunfado el León de la Tribu de Judá, el retoño de David"» (Repertorio).

105 Simbología de Cristo como Agnus Dei, que opera por contraste con la fiereza del león en el verso anterior.

106 Alude a uno de los pasajes más conocidos del Apocalipsis (capítulo 12) que narra la lucha entre 
Hombre (de rodillas) Juntos me han salido

el sol y la luna.

Todos Los Músicos ¿Quién creyera, cielos, tan gran ventura?

Y juntos me han salido

el sol y la luna.

Hombre ¿Quién creyera, cielos, tan gran ventura?

MúsICOS ¿Quién creyera, Hombre, tan gran ventura?

Hombre En medio de este trofeo, ¿a dónde volverme elijo? Que a esta parte veo al hijo y a esta a la madre veo. Susténtame aquel costado ${ }^{107}$, porque el alma le aproveche;

este pecho me da leche ${ }^{108}$ que al mismo Dios ha criado. En tan divinas señales, ¿qué escogeré por partido?

CRISTO Hombre, para ti han salido

MARÍA la luna y el sol celestiales. Ya vivir contento puedes, de hijo y madre regalado.

Hombre Tiénenme de mí robado tan soberanas mercedes.

CRISTO Obligado y satisfecho, el Adán Antiguo olvida, pues a costa de mi vida tan grande ganancia has hecho. Juego de importancia ha sido; tu dicha fue soberana pues el resto que se gana es haberte redimido.

El juego por ambos fue,

una mujer encinta y un dragón, resultando ella victoriosa. Es una representación de la Virgen en lid con Luzbel.

107 La sangre que mana del costado de Jesús, a consecuencia de la lanza introducida por el soldado Longino.

108 Advocación de la Virgen Nodriza que amamanta al hijo. 
y de él tomé para mí 1305 todas las quiebras, $\mathrm{y}$ en ti las ganancias renuncié. Goza tú todo el empleo, mas por obligarte a amarme, solo quiero yo quedarme con las cartas por trofeo. Pobre te vi entre esos dos, por mí envidian tus caudales; mira si medrado sales de la compañía de Dios. Vela mientras dura el día que mi sol hoy te concede.

HOMBRE Señor, noche haber no puede donde es la luna María.

MARÍA Favor tienes de mi parte porque Luzbel no te arguya, pon tú, Hombre, de la tuya, bien que pueda aprovecharte.

HOMBRE $\mathrm{Si}$ a las Indias de la corte celeste he de navegar, con vos estrella de mar $^{109}$ no puedo yo errar el norte.

CRISTO El llanto tanto aprovecha al justo, envuelto en su canto, que tras invierno de llanto viene agosto de cosecha. Trigo sembré, planté vides de que hacerte heredero, porque fundar en ti quiero el mayorazgo que pides; y están hoy tan sazonados, que te dan frutos opimos ${ }^{110}$ los mazuelos de racimos y de trigo los sembrados. Obreros míos, sacad,

109 Imagen de la Virgen como stella maris que guía el camino de los hombres, además de iluminarlos cuando el sol no está, actuando de forma complementaria a Cristo para acompañar a los fieles en todos los momentos de su vida cristiana. opimo: «Rico, fértil, abundante» (DRAE). 
briosos, fuertes, galanes, las hoces. Segad los panes, los racimos vendimiad, pues que darme determino en pan a hijos de Adán.

Sobre de mi cuerpo el pan, haya de mi sangre vino, que luego lo hagáis os mando. Cantad pues; la hoz se aplica, porque cosecha tan rica

ha de hacerse cantando.

SEgANDO UN CORO Gallarda cosecha los panes nos muestran.

Otro CORo Celestial vendimia tiene nuestra viña.

Celo De pan ofrenda te hacemos, con granos limpios y puros.

VERDAD Y los racimos maduros en tu lagar los ponemos.

CRISTO Del trigo que está crecido

la cizaña arrancad luego y sirva al eterno fuego.

Celo Estos, la cizaña han sido.

CRISTO Atadlos y haced gavillas de ellos.

Celo A este enlabio ${ }^{111}$ aparta.

VERDAD Vení acá vos cariharta ${ }^{112}$, que cuestan vuestras costillas más al cielo.

Muerte ¡En mí te ensaya!

CizAÑADOR ¡Que a un ángel se atrevan estos!

Átanlos, envuélvelos si puede ser, en algunas yerbas, cada uno hecho un manojo o gavilla en parte diferente.

Celo Bellamente quedan puestos.

111 enlabio: «Suspensión, engaño ocasionado por el artificio de las palabras» (DRAE); el sustantivo determina al personaje del Cizañador.

112 cariharta: «Redondo de cara» (DRAE); dibuja a la Muerte como un personaje de relativo peso físico, de ahí los dos versos siguientes. 
VERDAD Vade, vaya amigos.

HOMBRE

Vaya.

(Cantan dándoles vaya)

La Muerte y Luzbel vencidos, van a las eternas llamas.

¡Ucho, ho, que los corren las damas!

¡Ucho, ho, que van corridos!

CRISTO Hoy por mí, ilustras tu nombre.

MARÍA Del juego vas mejorado,

y en este triunfo, senado,

da fin el juego del Hombre.

Podrán volver a cantar si les pareciere, entrándose y cerrando las apariencias.

-Fin-

Recibido: $16 / 06 / 2015$

Aceptado: 1/09/2015

OBRAS CITADAS

Arellano, Ignacio (2011). Repertorio de motivos de los autos sacramentales de Calderón. Pamplona: Servicio de Publicaciones de la Universidad de Navarra. [En línea] $<$ http://dadun.unav.edu/handle/10171/20441> [Consulta: 06-02-2014]

ArelLANo, Ignacio, y J. Enrique Duarte (2003). El auto sacramental. Madrid: Laberinto.

BERGUA, Juan B. (1995). Pitágoras. Madrid: Imprenta Fareso.

CORREAS, Gonzalo (2000). Vocabulario de refranes y frases proverbiales [1627]. Madrid: Castalia.

CovarRuBias, Sebastián de (2006). Tesoro de la lengua castellana. Ignacio Arellano y Rafael Zafra (eds.). Madrid: Iberoamericana.

Diccionario de Autoridades (1726-1739), Real Academia Española. [En línea] <http://web. frl.es/DA.html> [Consulta: 06-02-2014]

Diccionario de la lengua española, Real Academia Española [En línea] <http://www.rae.es/ recursos/diccionarios/drae > [Consulta: 06-02-2014]

DuARTE, J. Enrique (1999). El divino Orfeo (segunda parte). Pamplona/Kassel: Universidad de Navarra/Reichenberger.

ÉtIENVRE, Jean Pierre (1990). Márgenes literarios del juego. Una poética del naipe: siglos $X V I-X V I I$. Londres: Tamesis.

Grimal, Pierre (2010). Diccionario de mitología griega y romana. Barcelona: Paidós.

ImBERT, Louis (1915). «El Juego del Hombre: Auto Sacramental». Hispanic Review, nº 3, pp. 239-282. 
Mejía de la Cerda, Luis (1625). Auto Sacramental del Juego del Hombre Fundado Sobre la Parábola del Sembrador y de la Cizaña. BNE, ms. 14873. [En línea] <http://bdh-rd. bne.es/viewer.vm?id $=0000098549$ \&page $=1>$ [Consulta: $20-01-2014]$

MenÉndez Pelayo, Marcelino (ed.) (1943). Autos y coloquios de Lope de Vega. Madrid: Atlas.

Rodríguez Ortega, Davinia (ed.) (2014). La semilla y la cizaña, de Pedro Calderón de la Barca. Pamplona/Kassel: Universidad de Navarra/Reichenberger.

(2015a). «Salió el sembrador a sembrar. Lope y Calderón, dos ingenios frente al género sacramental». Anuario Calderoniano, nº 8, vol. 1, pp. 335-354. (2015b). «Cristo como tahúr en el Auto sacramental del Juego del Hombre de Luis Mejía de la Cerda». Hipogrifo, $\mathrm{n}^{\circ}$ 3, vol. 1, pp. 223-236.

VV. AA. (1997-2004). Sagrada Biblia. Pamplona: Universidad de Navarra, 5 vols.

Auto sacramental del Juego del Hombre, de Luis Mejía de la Cerda. Edición crítica

Resumen: El presente artículo ofrece la edición crítica, transcripción y anotación, del Auto sacramental del Juego del Hombre, escrito por Luis Mejía de la Cerda en 1625. Pocos datos se conocen acerca del autor, quien fue relator en la audiencia de Valladolid; sin embargo, a pesar de no ser una obra literaria sobresaliente, es interesante por el modo en que recrea la parábola del sembrador y de la semilla y la cizaña, con la que también experimentaron Calderón de la Barca y Lope de Vega en los autos La semilla y la cizaña y La siega respectivamente.

Palabras clave: Auto sacramental, Juego del Hombre, parábola del sembrador, parábola de la cizaña, Lope de Vega, Calderón de la Barca.

Auto sacramental del Juego del Hombre, by Luis Mejía de la Cerda. A critical edition ABSTRACT: This text presents the critical edition, the transcription and annotation of the Auto sacramental del Juego del Hombre, written by Luis Mejía de la Cerda in 1625. There are few references about the author, who was a court report in Valladolid; therefore, thus it is not a remarkable piece of literature, it is interesting because of the way it explores the parables of the sower and the tares, the textual basis for the works by Calderón de la Barca and Lope de Vega, entitled La semilla y la cizaña and La siega, respectively.

KeYwords: Sacramental play, Juego del hombre, parable of the sower, parable of the tares, Lope de Vega, Calderón de la Barca. 
TERESA DE JESÚS (1515-1582)

Guillermo Serés (Universidad Autónoma de Barcelona)

La imaginación de Santa Teresa: virtudes y desatinos de «la loca de la casa»....... 11

Ana Garriga EsPino (Universidad Autónoma de Madrid)

El desafío editorial de las cartas de Teresa de Jesús.

LeCTURAS REPUBLICANAS DEL QUIJOTE

RAQUEL ArIas (Universidad Autónoma de Madrid)

León Felipe alista a don Quijote en el bando republicano. 57

MANUEl LóPez ForJas (Universidad Autónoma de Madrid)

El Quijote y la realidad viva de las Españas: la visión histórica

de Pedro Bosch-Gimpera.

CArmen Madorrán Ayerra (Universidad Autónoma de Madrid)

El Quijote como utopía necesaria: la mirada de Adolfo Sánchez Vázquez 85

\section{OTROS TEMAS}

SònIA BoADAS (Universitat Autònoma de Barcelona)

Libros y librerías: la recepción de Commynes en España 101

Lucila Lobato Osorio (Universidad Nacional Autónoma de México)

La noticia de la muerte de Policisne de Boecia: expresiones de dolor en un libro inconcluso.

María Gutiérrez Padilla (Universidad Nacional Autónoma de México)

La escenografía en el teatro caballeresco 131

ADRIÁn FERnÁNDEZ (Université de Fribourg)

Dos entremeses «auditivos» y sus niveles: hacia un metateatro visual. 145

David González de la Higuera Garrido (Universidad Complutense de Madrid) La visión premonitoria de Alonso en El caballero de Olmedo:

otra recuperación de lo popular

Esther Fernández LóPEz (UNED)

Perseo en la comedia tardobarroca: Ignacio Ferrera y Pasqual 169

Manuel Piqueras Flores (Universidad Autónoma de Madrid)

De La hija de Celestina $a$ La ingeniosa Elena: estructura narrativa, género literario e interpolación 
Dagoberto CÁceres Agullar (Western University Canada)

Realismo incesante: desde Celestina hacia su recepción 201

TeXTOS INÉDITOS

Davinia Rodríguez Ortega (Universidad Pública de Navarra)

Auto sacramental del Juego del Hombre, de Luis Mejía de la Cerda:

edición crítica 


\section{EDAD DE ORO}

Revista de Filología Hispánica XXXIV

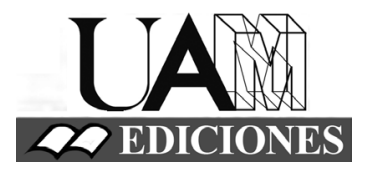




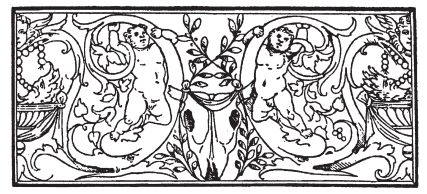

\section{Edad de Oro. Revista de Filología Hispánica}

ISSN: 0212-0429

Dirección:

Teodosio Fernández

Secretaría y edición:

José Ramón Trujillo

Comité científico internacional:

Carlos Alvar (Univ. de Ginebra)

Ignacio Arellano (Univ. de Navarra)

Javier Blasco (Univ. de Valladolid)

Alberto Blecua (UAB)

Jean Canavaggio (Univ. de París X)

Laura Dolfi (Univ. de Turín)

Aurora Egido (Univ. de Zaragoza)

Víctor García de la Concha (RAE)

Luciano García Lorenzo (CSIC)

Joaquín González Cuenca (Univ. de Castilla-

La Mancha)

Agustín de La Granja (Univ. de Granada)

Begoña López Bueno (Univ. de Sevilla)

Michel Moner (Univ. de Toulouse III)

Joan Oleza (Univ. de Valencia)

Alfonso Rey (Univ. de Santiago)

Lina Rodríguez Cacho (Univ. de Salamanca)

Leonardo Romero Tobar (Univ. de Zaragoza)

Aldo Ruffinatto (Univ. de Turín)

Lía Schwartz (City University of New York)
Redacción y admisión de originales:

Teodosio Fernández

Edad de Oro

Departamento de Filología Española

Universidad Autónoma de Madrid

28049 Madrid (España)

Tfno.: +0034914974090

correo: teodosio.fernandez@uam.es

Distribución, suscripción y venta:

Servicio de Publicaciones de la UAM

Universidad Autónoma de Madrid

28049 Madrid (España)

Intercambio de publicaciones:

Biblioteca de la Facultad de Filosofía y

Letras (UAM)

Universidad Autónoma de Madrid

28049 Madrid (España)

Han colaborado en este volumen:

Departamento de Filología Española (UAM)

Facultad de Filosofia y Letras (UAM)

Edad de Oro se recoge, entre otras, en las siguientes bases de datos: SCOPUS, MLA Database, HLAS, Latindex, PIO-Periodical Content Index, ISOC, Dialnet, MIAR, ERIH, DICE, Sumaris CBUC, Ulrich's. Se encuentra evaluada en CIRC: A; INRECH; MIAR difusión ICDS live: 9.977; SCImago Journal \& Country Rank: H Index 2, SJR 0,101, Q4; RESH índice de impacto: 0.041; ERIH: A INT1; Carhus Plus+ 2014: C. 